Dhaka Univ. J. Biol. Sci. 19(1): 1-11, 2010 (January)

\title{
IMPACT OF SOIL AMENDMENTS ON MACRONUTRIENTS (NA, K, CA, MG, N AND P) CONTENTS OF RICE GRAIN UNDER SUBSURFACE DRAINAGE IN SALT AFFECTED SOIL
}

\author{
R. MANDAL ${ }^{1}$ AND A.C. Aich \\ Benerpota Salinity Research Station, BWDB, Satkhira, Bangladesh \\ Key words: Soil amendment, Rice grain, Macronutrients, Subsurface drainage, \\ Salt affected soil
}

\begin{abstract}
Impact of soil amendments and brackish water irrigation on grain of three cultivars of rice provided with subsurface drained and non-drained conditions in saline soil was investigated. Contents of $\mathrm{Na}, \mathrm{Mg}, \mathrm{N}$ and $\mathrm{P}$ of rice grain increased significantly with increasing brackishness of irrigation water (ECiw 0.7 to $5.0 \mathrm{dS} / \mathrm{m}$ ) irrespective of drainage condition. The content of $\mathrm{Na}$ was found much lower in grain provided with subsurface drainage as compared with non drained ones irrespective of treatments and varieties. However, a reverse trend was observed in case of $\mathrm{K}$. Addition of both lime and gypsum alone caused a decrease in $\mathrm{Na}$ and an insignificant increase in Ca concentration at all levels of brackish water irrigation. Effect of lime and gypsum in presence of organic matter did not influence very much in $\mathrm{Na}, \mathrm{Ca}$ and $\mathrm{Mg}$ concentrations in all the cultivars. The contents of $\mathrm{N}$ and $\mathrm{P}$ increased with increasing levels of salinity might be due to stunted growth of plant caused by excessive $\mathrm{Na}$. Lime and gypsum alone caused a decline in the $\mathrm{P}$ content whereas organic matter alone helped to increase the same in grain of rice. Application of lime and gypsum along with organic matter failed to respond in $\mathrm{P}$ content significantly in grain of rice in all grades of brackish water whether provided with subsurface drainage or not. In both the sets, cow-dung influenced better performance than straw in mineral nutrition of rice grain.
\end{abstract}

\section{Introduction}

Salinity tolerance of rice has been observed to be associated with differential uptake of ions.(1-4) Salinity may adversely affect the mineral nutrition of the rice plant causing nutritional imbalance. The $\mathrm{K}$ content of rice straw decreased with increasing $\mathrm{Na}$ content suggesting an antagonism between $\mathrm{Na}$ and $K^{(5-7)}$, low concentration of $\mathrm{Ca}$ in the shoot of rice has been reported in saline condition. ${ }^{(6)}$ The yield of rice increased significantly due to subsurface drainage over non-drained condition. ${ }^{(8)}$ It is expected that the higher yield of rice due to subsurface drainage might be due to variation in

${ }^{1}$ Department of Soil, Water and Environment, University of Dhaka, Dhaka-1000, Bangladesh. 
mineral nutrients in grain as compared with non-drainage condition. Thus, an experiment was designed to see whether the application of organic, inorganic and physical amendments could possibly suppress the uptake of $\mathrm{Na}$ and help to enhance the accumulation of other macronutrients of rice grain.

\section{Material and Methods}

The experiment was conducted in saline soil ( $\mathrm{ECe} 13.5 \mathrm{dS} / \mathrm{m} ; \mathrm{pH} 5.8$ ) at Magura of Satkhira district. The land was divided into four blocks, two for non-drainage and the other two for subsurface drainage. Then each block was divided into three subblocks for irrigation with three grades of brackish water. Each irrigation subblock was further subdivided into three plots for two sources of organic matters and one for minus organic matter. Each plot was again divided into three split plots for gypsum, lime and without gypsum and lime. These split plots were further subdivided into three strips for three varieties of rice. The size of each strip plot was $4 \mathrm{~m}^{2}$. The treatment combinations used were as follows.

Brackish irrigation water (EC iw); Low $(0.7 \mathrm{dS} / \mathrm{m})$; medium $(2.50 \mathrm{ds} / \mathrm{m})$ and high $(5.0 \mathrm{dS} / \mathrm{m})$. Cow-dung (CD) and Straw (Str) : $\mathrm{CD}_{0} \mathrm{Str}_{0}=$ Organic Matter (0 t/ha), CD = $(10 \mathrm{t} / \mathrm{ha})$ and Str $=(10 \mathrm{t} / \mathrm{ha})$. Gypsum $(\mathrm{G})$ and lime $(\mathrm{L}): \mathrm{G}_{0} \mathrm{~L}_{0}=(0 \mathrm{t} / \mathrm{ha}), \mathrm{G}=(0.5 \mathrm{t} / \mathrm{ha})$ and $\mathrm{L}=(0.5 \mathrm{t} / \mathrm{ha})$ Rice cultivars: BR3, BR15 and Iratom 24 .

A total of 81 treatment combinations were arranged according to $3^{4}$ factorial split strip plot design with two replications. Each subblock was separated by 2 meter buffer zone and each plot was surrounded by a $1 \mathrm{~m}$ wide ridge. PK (80:60 kg/ha) and one third of the $\mathrm{N}(90 \mathrm{~kg} / \mathrm{ha}$ ) was applied as basal dose and the rest two-third of $\mathrm{N}$ was top dressed in two equal splits one at 30 days after transplantation (DAT) and the rest at 60 DAT. The organic matters were added seven days prior to transplantation and kept at field moisture condition. Gypsum and lime were applied on the surface soil of the plots at the time of final land preparation. Thirty five days old healthy seedling were transplanted as three seedlings in each hill spaced at 20 $\mathrm{cm} \times 20 \mathrm{~cm}$. The experimental blocks were irrigated with water of EC $1.2 \mathrm{dS} / \mathrm{m}$ during land preparation and also a ten days more after transplantation (survival stage), following by submergence of $2-5 \mathrm{~cm}$ standing water with brackish irrigation water.

Installation of subsurface drainage: For installation of subsurface drainage, trenches were made manually to a depth of $0.75 \mathrm{~m}$ and with a spacing of $2 \mathrm{~m}$. Uniform bamboos were selected. The average internal diameter of the bamboo was 65 $\mathrm{mm}$. The bamboos were splinted into two equal halves longitudinally. Internal nodes were carefully removed and half was bored $(0.5 \mathrm{~mm}$ dia) at an interval of $15 \mathrm{~cm}$ in a single line and the halves put together again and tied by nylon rope. A nylon net was used to cover the bamboo logs for protection against entrance of foreign materials 
into the log. Prepared bamboo logs were then placed on the ready trenches in such a way so that perforated halves remain on the top side with a slop of $0.1 \%$ and rice straw was spread around the logs. Cutout soils were replaced in the same order as was dugout. For consolidation of the fill soils surface irrigation was given manually with water of EC $1.2 \mathrm{dS} / \mathrm{m}$. The drainage logs were connected to outlet placed at $1 \mathrm{~m}$ depth from the surface.

Analytical techniques: Grain sample of rice was digested by diacid mixture of $\mathrm{HNO}_{3}$ and $\mathrm{HCIO}_{4}$ in $5: 2$ ratio following the method proposed by Yoshida et al. ${ }^{(9)}$ for chemical analysis of $\mathrm{Ca}, \mathrm{Mg}, \mathrm{Na}, \mathrm{K}$ and $\mathrm{P}$. Determinations were made of $\mathrm{Ca}$ and $\mathrm{Mg}$ by Atomic Absorption Spectrophotometer (model Hitachi 170-10), Na and K by Flame Emmission Spectrophotometery using a Flame Photometer (model corning EEL) and $\mathrm{P}$ as vanadomolybdophosporic acid complex spectrophotometrically. ${ }^{(9)} \mathrm{N}$ in a separate partion of grain sample, digested by $\mathrm{H}_{2} \mathrm{SO}_{4}$ and $\mathrm{HCIO}_{4}$ mixture, was estimated colorimetrically by Auto Analyzer (Technic S.O. colorimeter).

\section{Results and Discussion}

Impact of brackish water, organic matter, gypsum and lime in various combinations on the mineral content of rice grain of three cultivars provided with subsurface drainage and without drainage were determined and the results thus obtained are presented in Tables 1 to 6 .

Content of $\mathrm{Na}, \mathrm{Mg}, \mathrm{N}$ and $\mathrm{P}$ of rice grain increased significantly with the increase of brackishness of irrigation waters irrespective of treatments and varieties under drainage and non-drainage conditions (Tables 1, 4 - 6).

Sodium content of rice grain increased with the increase in brackishness of water but both gypsum and lime alone in all the irrigation waters generally retarded the accumulation of $\mathrm{Na}$ in all the varieties (Table 1). However, due to addition of organic matter (cow-dung/straw) along with gypsum or lime, the situation was not much different. It is also noticed that the content of $\mathrm{Na}$ in grain due to subsurface drainage was generally lower than that of subjected to non provision of drainage. The picture of $\mathrm{K}$ and $\mathrm{Ca}$ contents were, however, different that is their contents decreased with increase of brackishness of irrigation waters under non-drained and remained unchanged when provided with subsurface drainage (Tables 1 and 3). Addition of organic matters influenced the $\mathrm{K}$ content positively but that of gypsum or lime with organic matters (cow-dung/straw) could not make any difference in all cases. Application of cow-dung or straw alone or in combination with gypsum or lime did not show any beneficial effect significantly on the Ca content in grain. However, addition of gypsum or lime showed an increase in Ca content to some extent in most of the cases. Similarly, the $\mathrm{K}$ content also was found higher in grains subjected to subsurface drainage over non-drainage situation. The high content of $\mathrm{Na}$ coming 


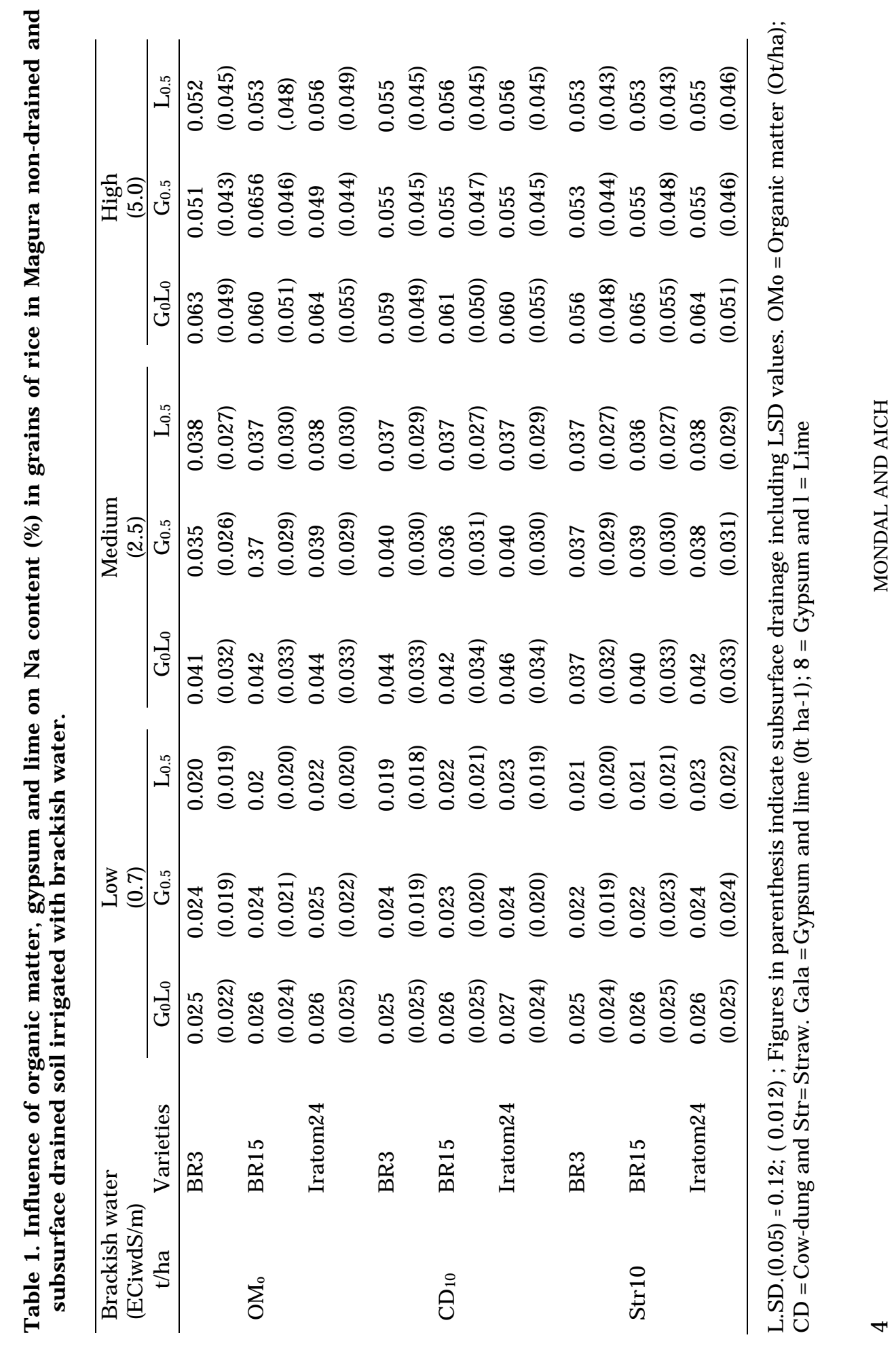




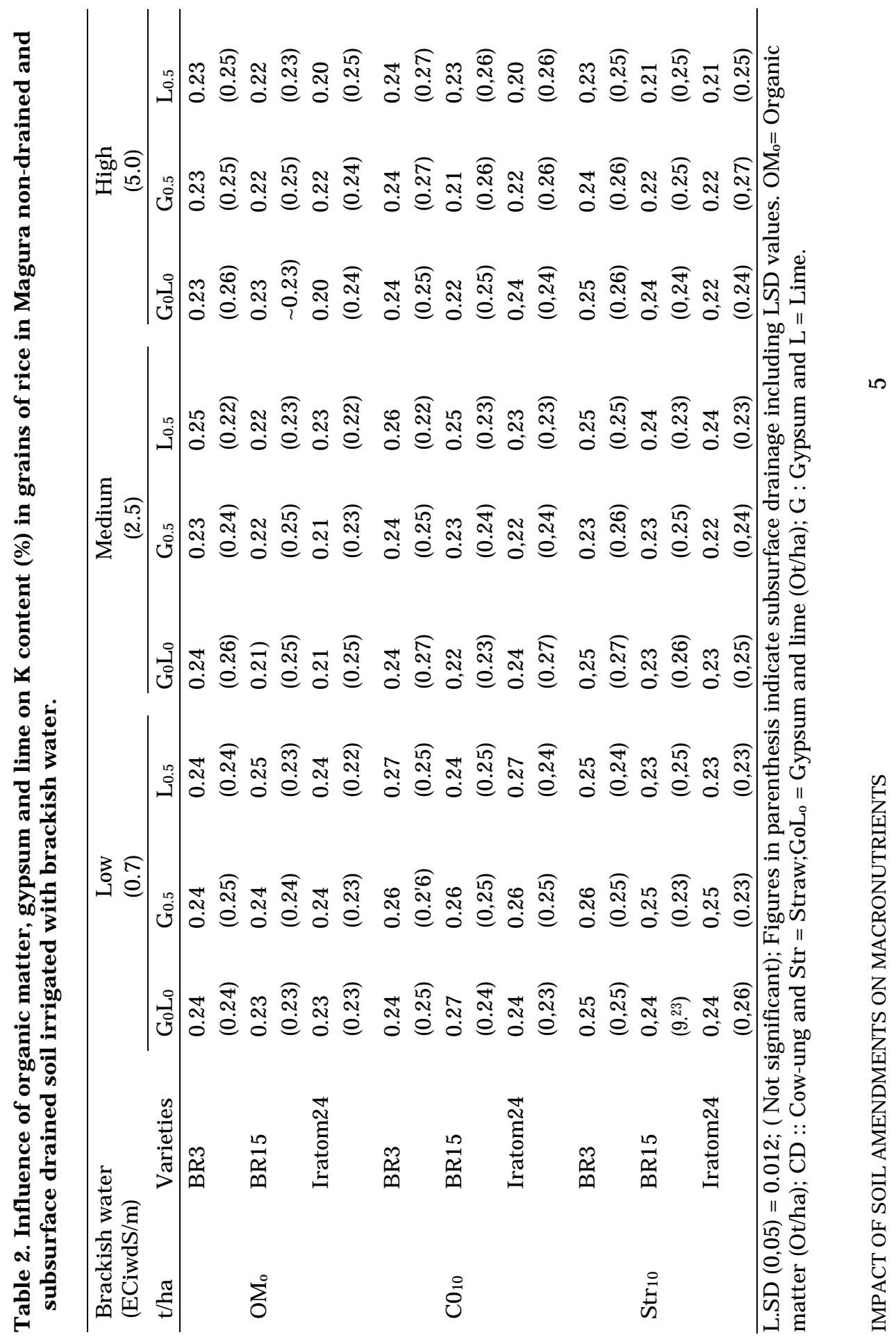




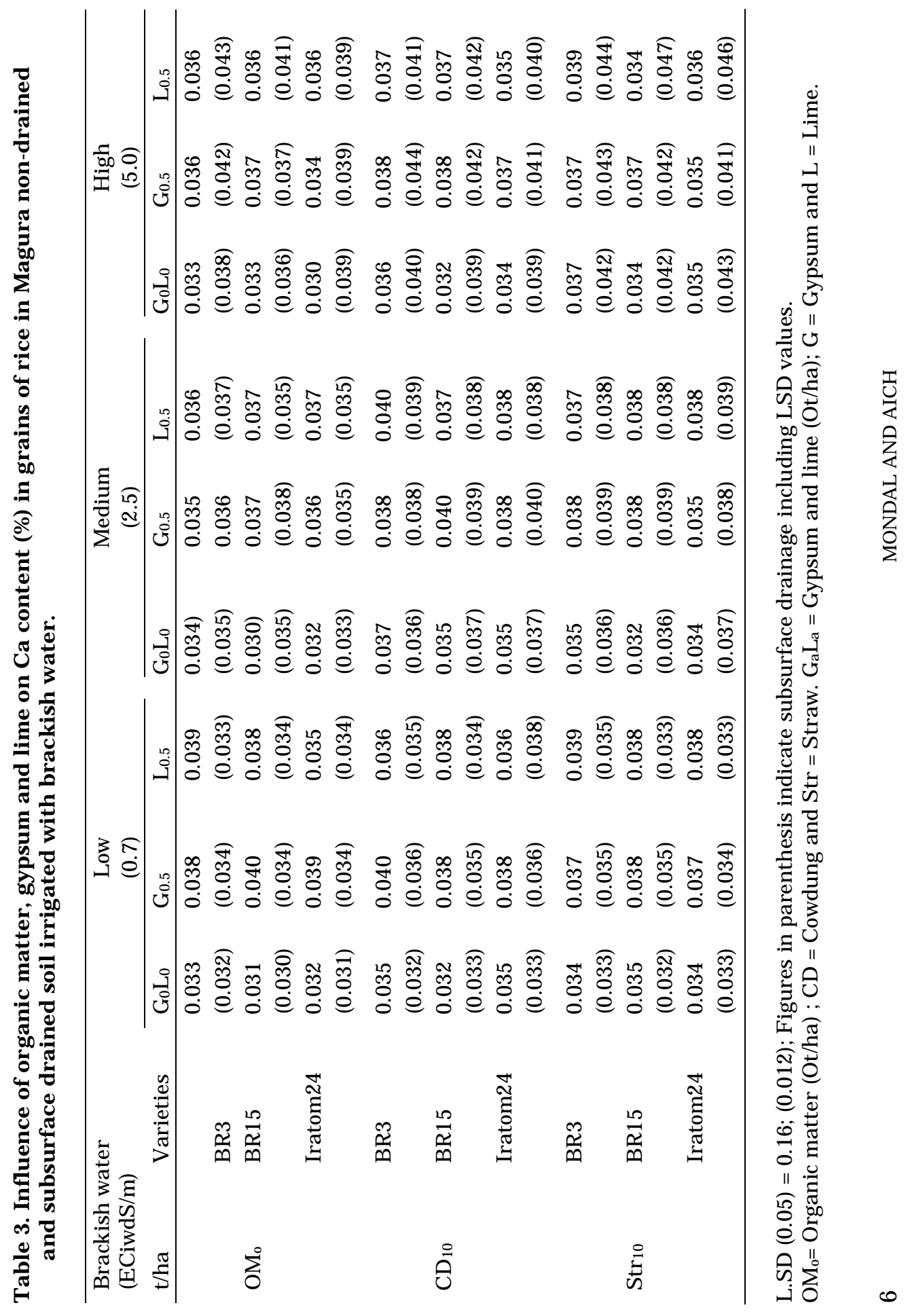




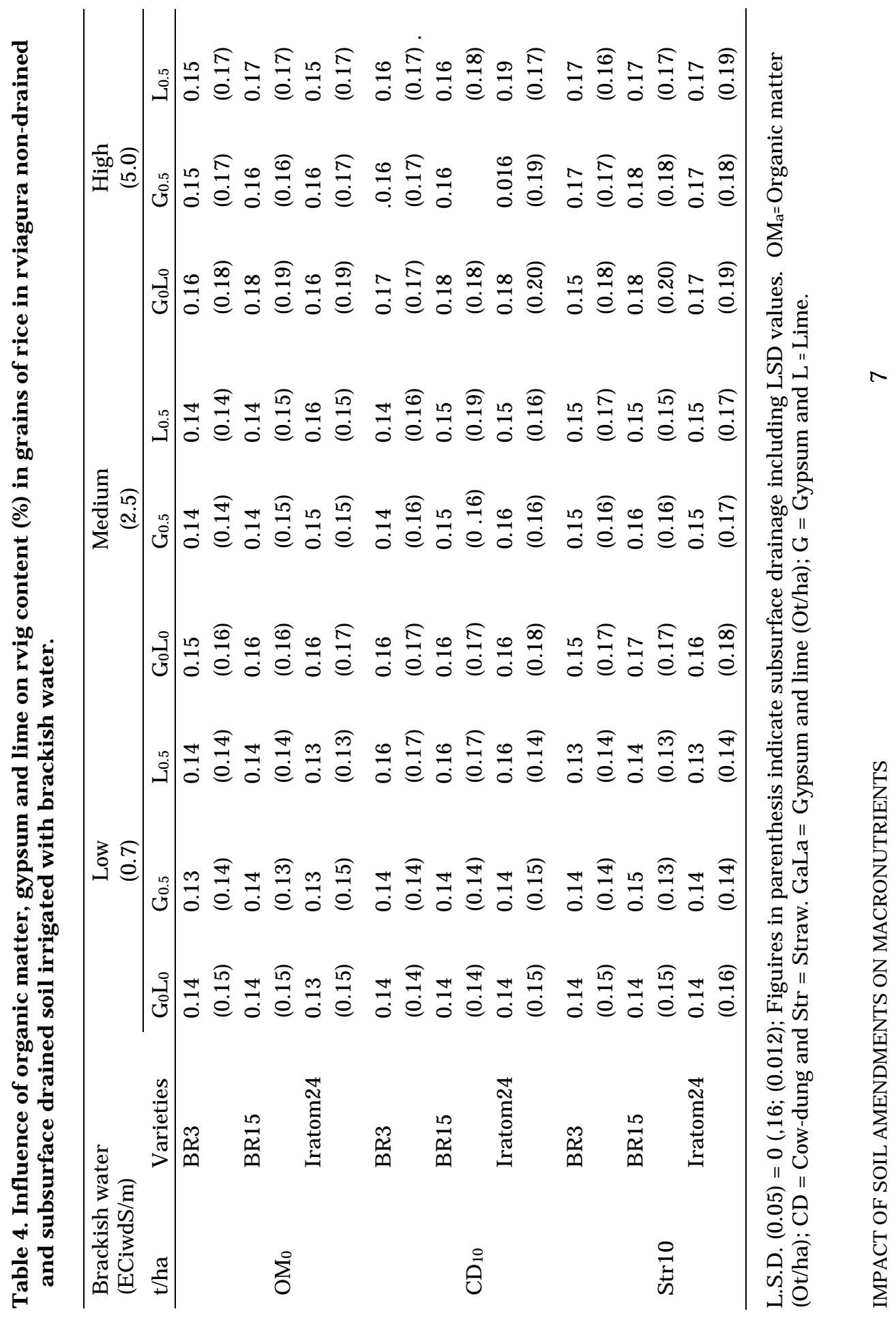




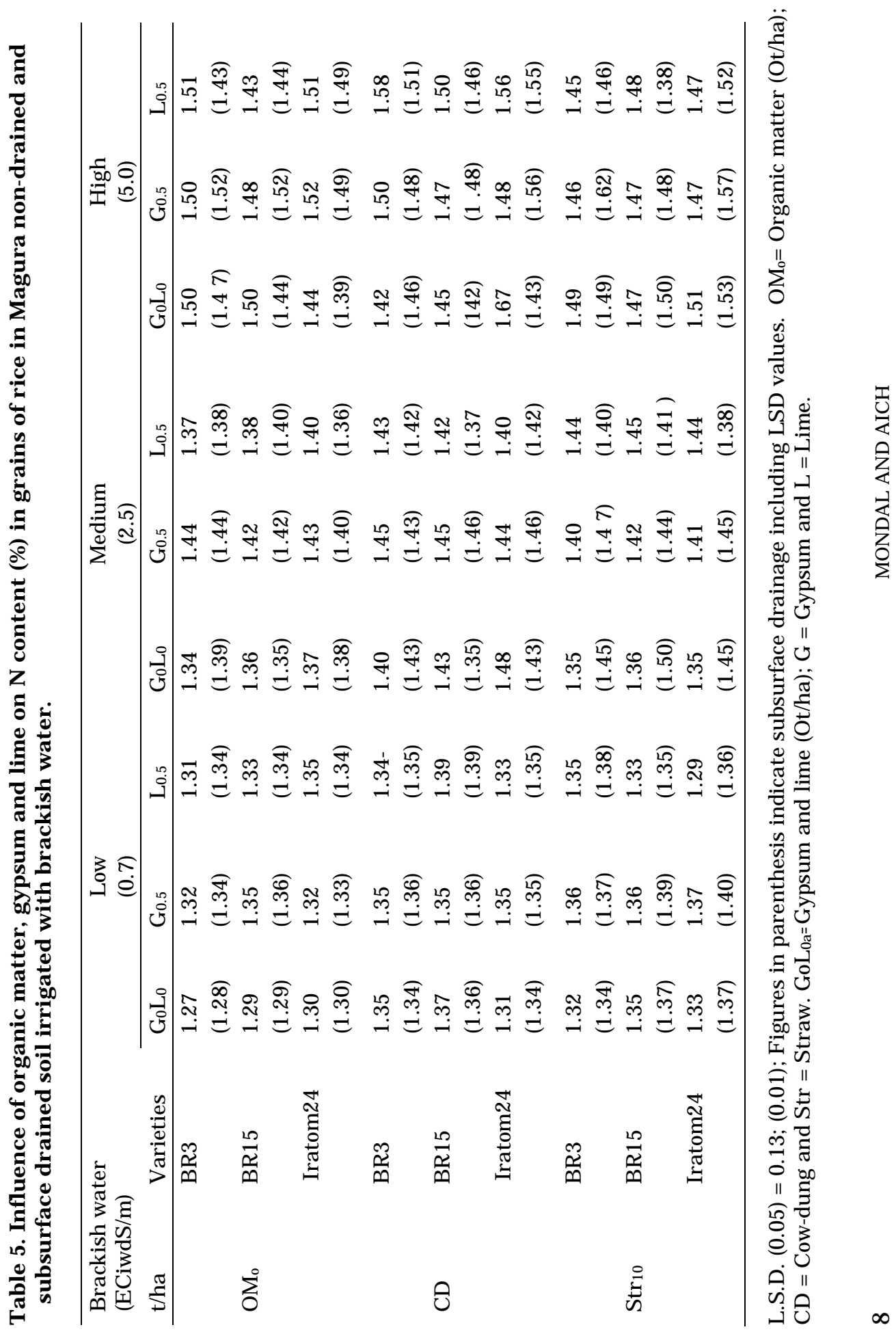




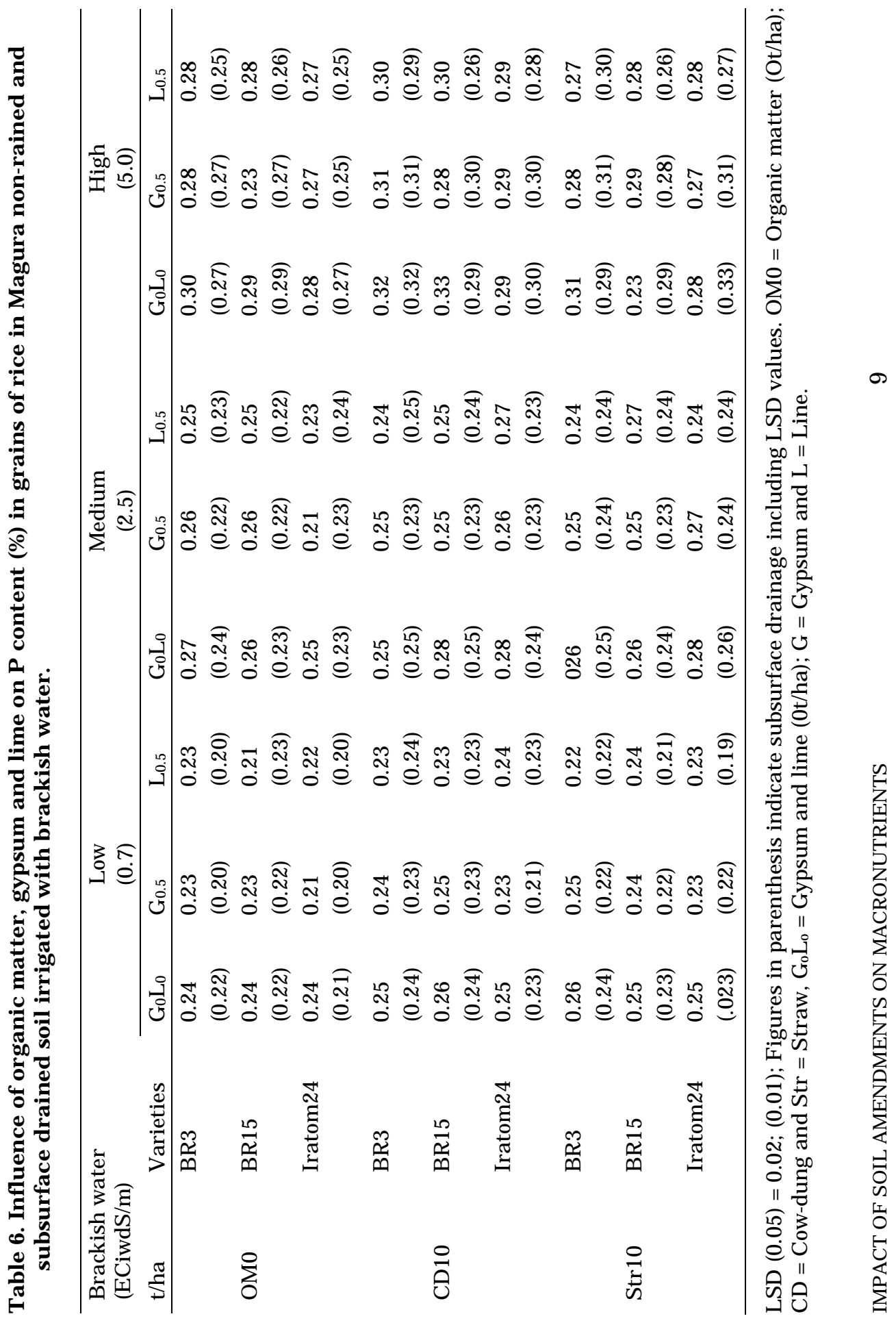


from brackish irrigation water might cause suppression of growth due to excess of $\mathrm{Na}$ and deficiency of $\mathrm{K}$ and $\mathrm{Ca}$. The higher content of $\mathrm{Na}$ and lower content of $\mathrm{K}$ indicate a nutritional imbalance with increasing salinity due to ion antagonism and can be related to exeess accumulation of $\mathrm{Na}$. A surplus of $\mathrm{Na}$ was shown to induce $\mathrm{K}$ deficiency in wheat plants growing in saline soil which was manifested in higher $\mathrm{Na} / \mathrm{K}$ ratio in the plants with increasing salinity.(10) Similarly, plants take up excessive amounts of $\mathrm{Na}$ at the cost of $\mathrm{K}$ and $\mathrm{Ca}$ grown in saline soil (11). In subsurface condition, $\mathrm{K}$ content was found higher and Na was lower than that of non drained condition. This might be the reason for which yield of rice was found higher in subsurface drained soil provided high brackish water irrigation (EC $5.0 \mathrm{dS} / \mathrm{m}$ ) as compared with non-drained soil under same situation in saline soil. ${ }^{(9)}$

The content of $\mathrm{Mg}$ and $\mathrm{P}$ of rice grain increased significantly with the increase of brackishness of irrigation water irrespective of treatments and varieties in both sets. However, in each water grade, gypsum, lime and organic matter individually or in combination did not contribute anything to $\mathrm{Mg}$ and $\mathrm{P}$ contents of rice grain (Tables 4 and 6). It is also found that the content of $\mathrm{Mg}$ was generally higher than $\mathrm{Ca}$. This situation may create harmful effect on plant nutrition causing significant reduction in growth and yield. Yadav and Girdhar ${ }^{(12-13)}$ stated that the excess absorption of $\mathrm{Mg}$ significantly depressed the uptake of both $\mathrm{K}$ and $\mathrm{Ca}$ by wheat plants creating a grossly imbalanced nutrients status and consequently growth and yield.

The content of $\mathrm{N}$ in grain increased significantly due to the application of gypsum and lime in all grades of irrigation waters, though a few data were not significant (Table 5). Organic matter (cow-dung/straw) as found more potent when applied together with lime/gypsum and the increases were significant burring a few cases.

The increase of $\mathrm{N}$ and $\mathrm{P}$ content due to brackishness had happened haply due to the stunted growth of the plant caused by excessive $\mathrm{Na}$ and possibly the uptake of $\mathrm{N}$ and $\mathrm{P}$ remained the same but the growth was not so much as in low brackish water. Girdhar ${ }^{(14)}$ reported that salinity increased the $\mathrm{N}$ content of rice plant. Rice grown in saline soil has higher $\mathrm{N}$ and lower $\mathrm{K}$ content than nonsaline one. ${ }^{(7)}$

\section{References}

1. Flowers TJ 1985. Physiology of halophytes. Plant and Soil. $89: 41-56$.

2. Gorgham JAG, Wyn Jones and E Mc Donnel 1985. Some mechanisms of salt tolerance in crop plants. Plant and Soil. 89: 15-40.

3. Flowers TJ and AR Yeo 1991. Variability in the resistance to sodium chloride salinity with in rice varieties, New Phylol. 88: 363-373.

4. Quayyum HA, GM Panaullah and MZ Haque 1991. A comparative study of osmotic and ionic effects of salinity on two rice varieties. Pokkali and MI-48. Bangladesh J. Bot. 20(2): 137-142. 
5. Akbar M, GS Khush and D Hillerislambers 1986. The genetic of salt tolerance in rice. Rice genetics. Proc. Intern. Richgenetics Sym. 27-31 May 1985. Manila. Philippines. 399409.

6. Arjuna A and S Chandrasekaran 1988. Tolerance in rice (Oryza sativa L.) in relation to salt uptake and yield. Indian J. Plant Physiol. 31(4): 403-406.

7. Qureshi R and M Akbar 1990. Effect of saline soil on grain quality of rice different in salinity tolerance. Plant Fd. Human Nutrin 40: 31-36.

8. Yoshida S, DA Forno, JH Cock and KA Gomez 1972. Laboratory manul for physiological studies of rice. $2^{\text {nd }}$ Ed. Intern.Rice Res. Inst., Los Banos, Philippines. 1-70.

9. Aich AC, R Mandal and AHM Ahmed 1996. Study of economic feasibility of agricultural subsurface drainage in saline soil of Bangladesh. J. Indian Soc. Coastal Agroc. Res. 14(1\& 2): 87-91.

10. Finck A 1977. Soil salinity and plant nutritional status. In: Managing Saline Water for Irrigation. (ed.E. Dregne). Texas. Tech. Univ., Lubboek, Taxas.

11. Kuiper PJC 1984. Functioning of plant cell membrance under saline conditions. Membrane lipid composition and ATP ases. In: Salinity tolerance in plants. Staples R C and G H Toenniessen. pp 77-91. Wiley Inter Science, New York.

12. Yadav JSP and IK Girdhar 1980. Effect of varying $\mathrm{Mg} / \mathrm{Ca}$ ratio and electrolyte concentration in the irrigation water on the soil properties and growth of wheat. Plant and Soil. 56: 413-427.

13. Yadav JSP and IK Girdhar 1981. The effect of different magnesium: calcium ratios and sodium absorption ratio values of leaching water on the properties of calcareous VS noncalcareous soil. Soil Sci. 131: 194-198.

14. Girdhar IK 1988. Effect of saline irrigation water on the growth, yield and chemical composition of rice crop in a saline soil. J. Indian Soc. Soil. Sci, 36(2): 324-329.

(Manuscript received on 23 December, 2008; revised on 4 March, 2009) 